\title{
A Clinically Useful Method for Detecting Gonadotropins in Children: Assessment of Luteinizing Hormone and Follicle-Stimulating Hormone from Urine as an Alternative to Serum by Ultrasensitive Time-Resolved Immunofluorometric Assays
}

AND DEMIR, HENRIK ALFTHAN, ULF-HÅKAN STENMAN, AND RAIMO VOUTILAINEN

Departments of Pediatrics [A.D., R.V.] and Clinical Chemistry [H.A., U.-H.S./, Helsinki

University Central Hospital, FIN-00290 Helsinki, Finland

\section{ABSTRACT}

To study the feasibility of noninvasive sampling in pediatric patients, we examined the concentrations of $\mathrm{LH}$ and FSH in paired serum and urine samples from 65 children (age 0-15 y) with highly sensitive time-resolved immunofluorometric assays. The detection limits of the assays were $0.015 \mathrm{IU} / \mathrm{L}$ for $\mathrm{LH}$ and $0.018 \mathrm{IU} / \mathrm{L}$ for $\mathrm{FSH}$. These sensitivity levels allowed quantification of the low prepubertal LH and FSH concentrations. The correlation between serum and urine gonadotropin values was very good $(r=0.751, p<0.001$ for $\mathrm{FSH}$; and $r=0.720, p<0.001$ for LH), and the urine and serum concentrations were very similar. Correction of urinary gonadotropin concentrations

Urine sampling has made a comeback in pediatric endocrinologic diagnostics as a result of efforts to avoid repeated, invasive blood sampling. Much interest has been focused in particular on GH in urine (1). RIA methods were not sensitive enough to measure urinary GH levels (2), but measurement of urinary GH levels became possible using more sensitive immunoassays like the immunoradiometric assay (3), sandwich enzyme immunoassay (4), and IFMA $(5,6)$. The situation has been similar for the gonadotropins. The presence of gonadotropins in prepubertal urine was first demonstrated in the 1960 s by Fitschen and Clayton (7) and Kulin et al. (8) using bioassay and by Bagshawe et al. using RIA (9). In 1970, FSH and $\mathrm{LH}$ were quantitatively measured in urine by Rifkind et al. (10) using RIA. To improve sensitivity, extraction and concentration methods were later included and bet-

Received September 9, 1993; accepted March 3, 1994.

Correspondence and reprint requests: And Demir, M.D., Children's Hospital, University of Helsinki, Stenbäckinkatu 11, FIN-00290 Helsinki, Finland.

Supported by grants from the Pediatric Research Foundation and the Finnish Cancer Foundation. for changes in urinary flow by standard methods using density [concentration $\times(0.02 /$ density -1$)$ ] or creatinine (concentration/creatinine) did not improve the correlation. Therefore, measurement of urinary gonadotropins without correction can simply be used in the pediatric outpatient setting as a noninvasive alternative to serum determinations. (Pediatr Res 36: 221-226, 1994)

GH, growth hormone
IFMA, immunofluorometric assay

ter accuracy was obtained by using timed urine samples (11). However, in spite of extraction and concentration, prepubertal levels remained "below threshold" with the detection limits of RIA. In addition, RIA-detectable low gonadotropin levels in serum were possibly overestimates because of nonspecific interference $(6,12-15)$.

Urinary FSH and $\mathrm{LH}$ measurements can reflect the total 24-h production and have been applied to 24-h or shorter timed urine samples $(11,16,17)$. In 1980, Bourguignon et al. (18) published an extensive study of unextracted urinary gonadotropin levels in timed fractions of 24-h urine that showed a morning increase of gonadotropin excretion and a circadian pattern at the onset of puberty. Because the 24 -h urine collection procedure is rather impractical and, particularly in the pediatric age group, may be unreliable, first morning voided urine has been proposed to reflect the 24-h output (19). In 1987, Girard and Hadziselimovic (20) suggested that urinary gonadotropin measurements in the first morning voided urine can be used for differential diagnosis of pubertal disorders and for the follow-up of hormone treatment. 
They used urine extraction to increase the sensitivity of the assay. Maesaka et al. $(21,22)$ observed good correlation between the first morning voided and full 24 -h urine gonadotropin concentrations. They used polyclonal double-antibody RIA after ammonium sulfate extraction.

Recently, rapid and ultrasensitive immunoassays have been developed (23). This has allowed determination of the low prepubertal gonadotropin concentrations in serum (6), and this method can also be used for urine measurements (24). Gonadotropin IFMA have been successfully used to measure very low serum FSH and LH levels $(6,15,25-29)$.

To study whether it is possible to replace invasive serum determinations by urinary FSH and LH measurements in children, we used highly sensitive IFMA. We also evaluated the use of urinary density or creatinine correction to compensate for variations in urine flow and improve the correlation with serum levels.

\section{METHODS}

Subjects. Paired serum and urine samples were taken from 65 children ( 22 girls and 43 boys) aged $0-15 y$. They had no endocrinologic, nephrologic, oncologic, or neurologic disorders, and they had not received medication affecting endocrine (hypothalamic or hypophyseal) or kidney function during the sampling period. The samples were taken between 0800 and $1000 \mathrm{~h}$. Mostly, they were not first morning voided urine samples, inasmuch as we studied outpatients. Urine samples from 11 adults (six males, five females) were used to study the stability of urinary gonadotropins at different temperatures $\left(20^{\circ} \mathrm{C}\right.$, $4^{\circ} \mathrm{C}$, and $-20^{\circ} \mathrm{C}$ ) and with different additives (sodium azide and thymol).

Protocol. The clinical studies were conducted at the Children's Hospital, and the assays were carried out in the Department of Clinical Chemistry, Helsinki University Central Hospital. The protocol was approved by the ethical committee of the Children's Hospital.

Sample storage. Urine samples were routinely stored at $4^{\circ} \mathrm{C}$ without preservatives. Urine tubes were coated with BSA (Boehringer Mannheim, Fraction V, Mannheim, Germany) by rotation of one-third-filled tubes overnight using 2 or $20 \mathrm{~g} / \mathrm{L}$ of BSA. The effect of sodium azide was studied using a concentration of $1 \mathrm{~g} / \mathrm{L}$. Thymol was tested as a preservative at a concentration of $20 \mathrm{~g} / \mathrm{L}$. Propylene tubes were preferred to avoid sticking of gonadotropins onto the inner walls.

Urine and serum FSH and LH concentrations were measured in duplicate by DELFIA IFMA $(23,24)$ using reagents obtained from Wallac (Turku, Finland) with minor modifications as described below. The assays are solid-phase, two-site IFMA assays using two MAb directed against separate antigenic determinants on the gonadotropins. Antibodies to the $\beta$-subunit are immobilized by passive coating onto the walls of microtiter wells. The indicator antibody, specific for the $\alpha$-subunit, is labeled with a europium chelate.
The assay is performed as a two-step procedure. The sample is first reacted with immobilized catcher antibodies for $2 \mathrm{~h}(\mathrm{LH})$ or $3 \mathrm{~h}$ (FSH). After washing the wells, europium-labeled indicator antibody is added. After further incubation $(1 \mathrm{~h})$ and a second wash, enhancement solution is added. This solution dissociates europium ions from the labeled antibody into the mixture, where they form highly fluorescent chelates with components of the enhancement solution. The fluorescence is proportional to the quantity of gonadotropin in the sample. The fluorescence is measured for $1 \mathrm{~s}$ per sample in an Arcus 1230 fluorometer (Wallac). Hormone concentrations were corrected for variations in urinary excretion using the following formulas: creatinine-corrected concentration = concentration/creatinine (IU/mol), or density-corrected concentration $=$ concentration $\times(0.02 /$ density -1$)($ IU $/ L)$.

Statistical methods. The relationship between urinary and serum gonadotropin concentrations was analyzed using correlation and regression analysis. The Fisher's $r$ to $z$ test was used for checking the statistical significance of the correlation. The detection limit was defined as the concentration corresponding to the mean value of 12 duplicates of the zero standard plus 2 SD. For statistical evaluation, concentrations below the detection limit were given the value $0.01 \mathrm{IU} / \mathrm{L}$. The effect of various incubation times (1-20 h) and sample volumes was evaluated. Sample volume was varied from $25 \mu \mathrm{L}$ to $200 \mu \mathrm{L}$, keeping the total incubation volume at $225 \mu \mathrm{L}$.

\section{RESULTS}

Sensitivity. The detection limit of the FSH assay was $0.018 \mathrm{IU} / \mathrm{L}$ and that of the LH assay was $0.015 \mathrm{IU} / \mathrm{L}$. The intraassay and interassay variations ranged between 2.3 and $7.8 \%$ and 5.2 and $8.7 \%$, respectively.

Effect of incubation time. The detection limits for 2-h, 3 -h, and overnight incubations for LH were $0.015,0.018$, and $0.023 \mathrm{IU} / \mathrm{L}$, respectively, whereas for FSH the corresponding values were $0.020,0.018$, and $0.018 \mathrm{IU} / \mathrm{L}$, respectively. The best sensitivity was obtained with an incubation time of $2 \mathrm{~h}(\mathrm{LH})$ or $3 \mathrm{~h}(\mathrm{FSH})$. The detection limit for LH was slightly better than that obtained with a 1-h incubation, i.e. $0.019 \mathrm{IU} / \mathrm{L}$ (6). Extension of the incubation time overnight did not improve the sensitivity.

Effect of sample volume. Lower-than-expected results were obtained when the sample volume was increased, and the error was proportional to increasing sample volume (Fig. 1).

Effect of storage temperature. Urinary gonadotropin levels were fairly stable at $4^{\circ} \mathrm{C}$. On average, $93.3 \%$ of $\mathrm{FSH}$ and $95.1 \%$ of $\mathrm{LH}$ was recovered by the end of $7 \mathrm{wk}$. Freezing caused a clear decrease in urinary FSH (down to $76.9 \%$ ) and urinary $\mathrm{LH}$ concentrations (down to $77.4 \%$ ) in $7 \mathrm{wk}$. Storage at room temperature caused a marked decrease in urinary gonadotropin levels (down to 71.0 and $43.8 \%$ for FSH and LH, respectively) by the end of the 7-wk period (Fig. 2, Table 1). Repeated freezing and thawing of samples decreased the urinary FSH and 

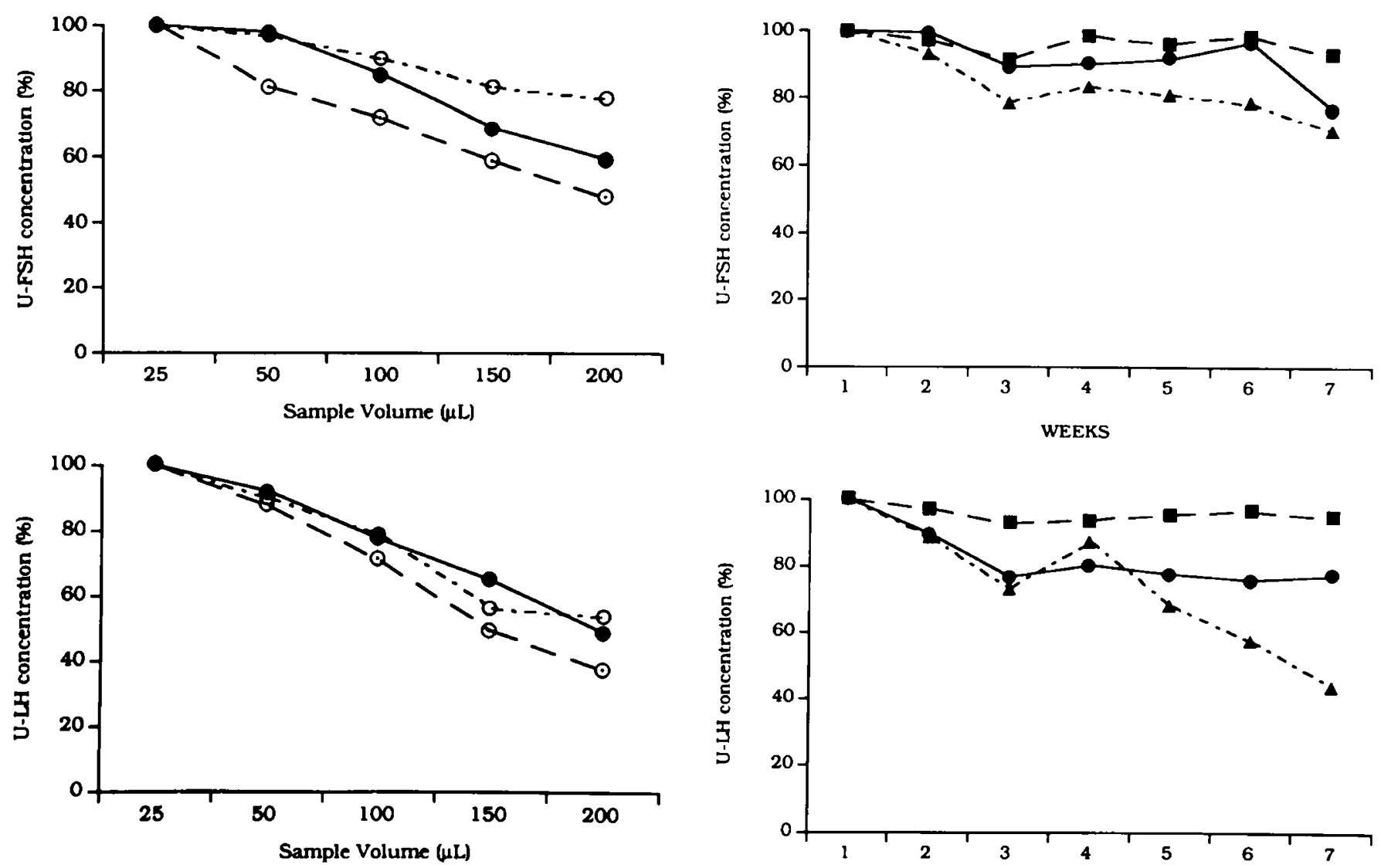

Figure 1. Effect of sample volume on recovery of $\mathrm{LH}(U \cdot L H)$ and FSH $(U-F S H)$ in urine. Three different samples are shown. The result obtained with a $25-\mu \mathrm{L}$ sample volume was set at $100 \%$.

LH levels (average drop of 48.7 and $47.3 \%$, respectively, at three freeze-thaw cycles).

Effect of coating sample tubes. Coating of the tube walls with different concentrations of BSA did not affect the recovery of gonadotropins (data not shown).

Effect of additives. The addition of sodium azide or thymol as a preservative had no influence on urinary FSH or $\mathrm{LH}$ values when the samples were stored at $4^{\circ} \mathrm{C}$ for up to 7 wk (data not shown).

Correlation between urine and serum gonadotropin concentrations. Urinary gonadotropin levels correlated well with the corresponding serum levels. Correction for variations in urinary flow did not improve the correlation (Figs. 3 and $4)$, and in very dilute urine samples $(\mathrm{d} \leq 1.007)$, the correlation was impaired by correction for either urinary density or creatinine (Table 2). Particularly, the correction for creatinine was too large (Figs. $3 C$ and $4 C$ ).

Table 3 shows examples of urinary and serum gonadotropin concentrations in four healthy children and two girls with Turner syndrome. The data show that urine and serum gonadotropin concentrations are very close to each other also in situations where the concentrations are higher than normal.

\section{DISCUSSION}

Diagnostic sampling is a delicate matter in pediatric practice, and invasive methods should be avoided as

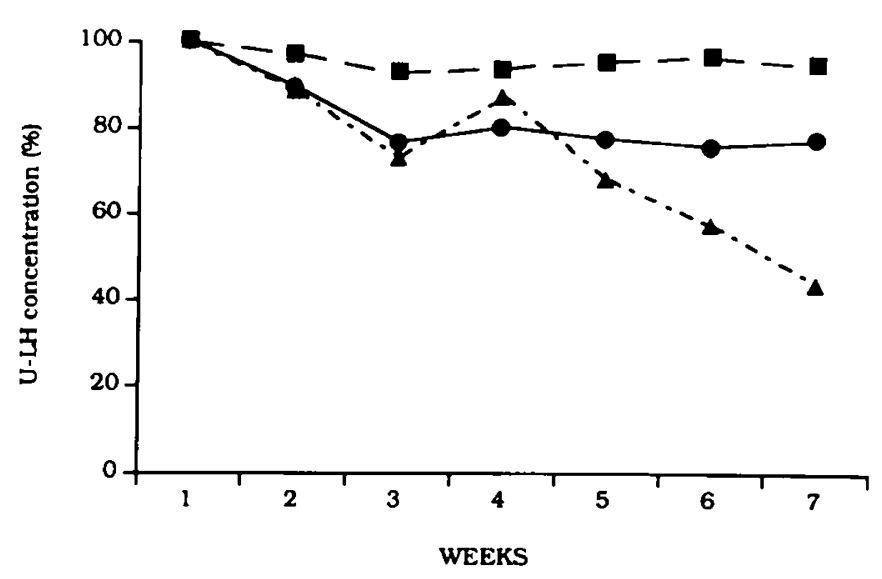

Figure 2. Mean urinary gonadotropin concentrations (U-FSH and $U-L H)$ (expressed as a percentage of the initial concentration) during the 7 -wk course of storage for different temperatures $\left[-20^{\circ} \mathrm{C}(\bullet), 4^{\circ} \mathrm{C}\right.$ $(\square)$, and $\left.20^{\circ} \mathrm{C}(\boldsymbol{\Delta})\right]$.

Table 1. Effect of storage at different temperatures on urinary gonadotropins during the course of $7 w k$ storage

\begin{tabular}{llccc}
\hline Temperature & Hormone $^{*}$ & Range $(\%)$ & Mean $(\%)$ & $n$ \\
\hline Freezer & U-FSH & $66.6-94.0$ & 76.9 & 10 \\
Freezer & U-LH & $39.5-94.5$ & 77.4 & 11 \\
Refrigerator & U-FSH & $88.2-99.0$ & 93.3 & 10 \\
Refrigerator & U-LH & $71.4-99.9$ & 95.1 & 11 \\
Room & U-FSH & $35.3-90.6$ & 71.0 & 10 \\
Room & U-LH & $24.3-54.2$ & 43.8 & 11 \\
\hline
\end{tabular}

* U-FSH, urinary FSH; U-LH, urinary LH.

much as possible. Urinary hormone measurements are simple and noninvasive. The sensitivity of the present IFMA is $50-100$ times greater than that of conventional RIA methods. This allows determination of low prepubertal urinary gonadotropin concentrations without extraction or concentration of urine samples. This sensitivity was achieved with a small sample volume, which is essential for eliminating nonspecific effects caused by variations in the composition of urine (30). Thus, these methods are suitable for assay of urine samples.

Some of the previously reported ratios of bioactive to immunoreactive gonadotropin concentrations based on RIA methods are presently considered unreliable, inasmuch as conventional RIA methods tend to overestimate low LH levels $(6,12-15)$ because of nonspecific interfer- 


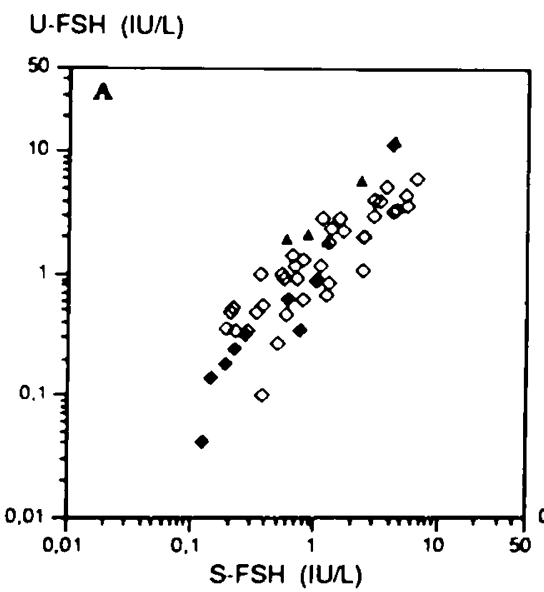

U.FSH (IU/L) (density-orrecled)

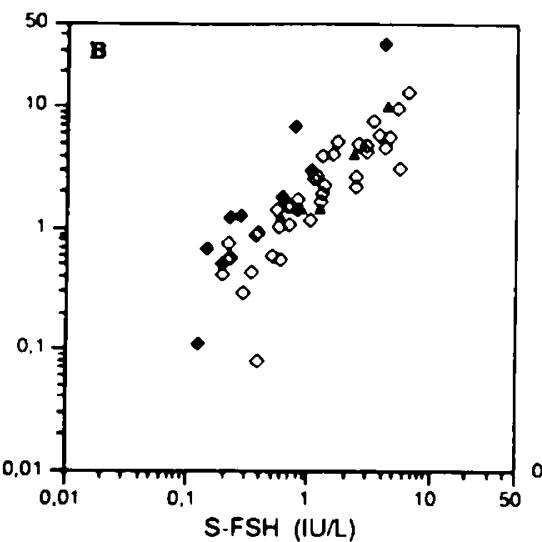

U-FSH (IU/mol urinary creatinine)

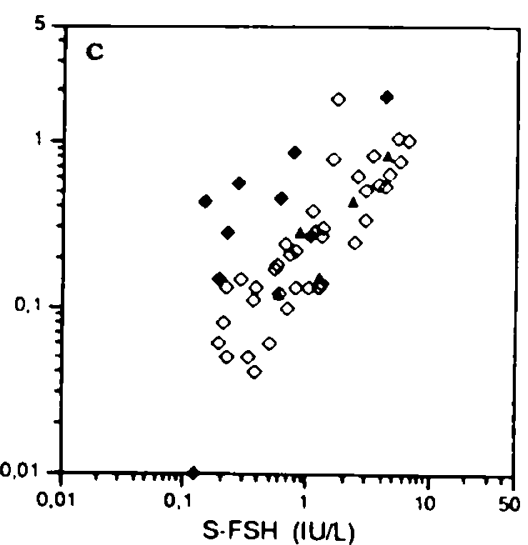

Figure 3. Correlation between uncorrected $(A)$, density-corrected $(B)$, and creatinine-corrected $(C)$ urinary FSH concentrations $(U-F S H)$ and corresponding serum FSH concentrations $(S-F S H)$. The symbols represent samples with various densities [normal density $(\diamond ;$ density $=$ $1.008-1.024)$, dilute $($, density $\leq 1.007)$, and concentrated $(\Delta ;$ density $\geq 1.025)$ urine samples].
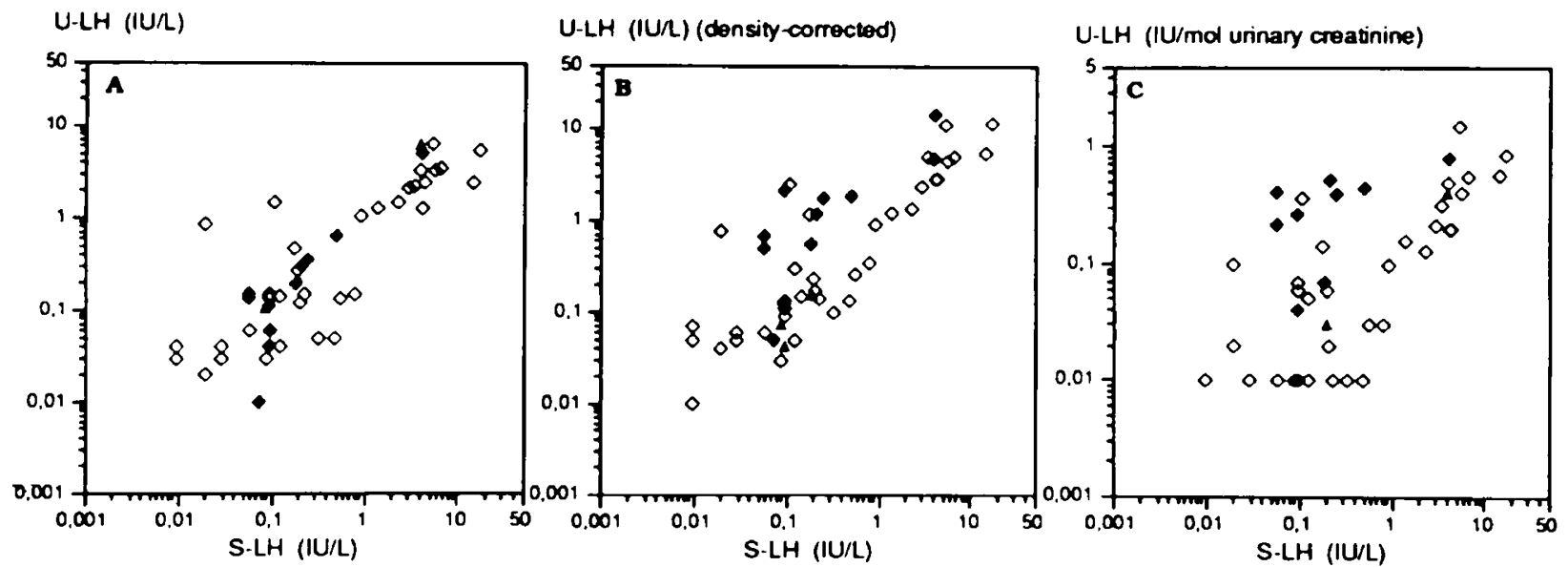

Figure 4. Correlation between uncorrected $(A)$, density-corrected $(B)$, and creatinine-corrected $(C)$ urinary LH concentrations $(U-L H)$ and corresponding serum LH concentrations $(S-L H)$. See Figure 3 for an explanation of the symbols.

ence by serum components (30). In this respect, immunometric assays are advantageous because of their higher specificity and sensitivity, making measurement of very low serum LH and FSH concentrations possible. On the other hand, our assays as well as many other immunoassays may underestimate urinary gonadotropin levels to some extent, inasmuch as the gonadotropins are degraded in the kidneys and then excreted in urine in different immunoreactive forms (i.e. $\beta$-subunits and $\beta$-core fragments) (31-34). Because our method requires the presence of both $\alpha$ - and $\beta$-subunits, we measured only intact LH and FSH but not their fragments.

Table 2. Correlation between uncorrected, density-corrected, and creatinine-corrected urinary gonadotropin concentrations

\begin{tabular}{cccc}
\multicolumn{3}{c}{ and the corresponding serum values $(\mathrm{n}=65)^{*}$} \\
\hline Comparison & Uncorrected & $\begin{array}{c}\text { Density } \\
\text { corrected }\end{array}$ & $\begin{array}{c}\text { Creatinine } \\
\text { corrected }\end{array}$ \\
\hline U-FSH:S-FSH & $r=0.751 ;$ & $r=0.642 ;$ & $r=0.643 ;$ \\
& $p<0.0001$ & $p<0.0001$ & $p<0.0001$ \\
U-LH:S-LH & $r=0.720 ;$ & $r=0.742 ;$ & $r=0.644 ;$ \\
& $p<0.0001$ & $p<0.0001$ & $p<0.0001$ \\
\hline
\end{tabular}

\footnotetext{
* U-FSH, urinary FSH; S-FSH, serum FSH; U-LH, urinary LH;
} S-LH, serum LH.
Various procedures for improving sensitivity over the standard method were studied. Increasing the assay incubation time from $1 \mathrm{~h}$ to 2 or $3 \mathrm{~h}$ was useful. Sample volumes larger than $25 \mu \mathrm{L}$ caused nonspecific inhibition (30), evidenced by lower than expected recovery. Urinary gonadotropins were stable at refrigerator temperature for several weeks, whereas freezing reduced the concentrations in some samples. Thus, the patient's family can store the urine sample in a refrigerator until delivery to the hospital. Livesey et al. (35) also reported

Table 3. Comparison of urinary and serum gonadotropin concentrations in four healthy children and two girls with Turner syndrome*

\begin{tabular}{lcccrrr}
\hline \multicolumn{1}{c}{ Diagnosis } & Sex & Age $(y)$ & $\begin{array}{c}\text { U-FSH } \\
\text { (IU/L) }\end{array}$ & $\begin{array}{r}\text { S-FSH } \\
\text { (IU/L) }\end{array}$ & $\begin{array}{r}\text { U-LH } \\
\text { (IU/L) }\end{array}$ & $\begin{array}{r}\text { S-LH } \\
(\text { IU/L) }\end{array}$ \\
\hline Healthy & F & 12.5 & 6.14 & 6.71 & 5.29 & 17.61 \\
Healthy & F & 13.8 & 4.36 & 5.45 & 2.43 & 15.20 \\
Turner syndrome & F & 13.1 & 88.1 & 103.40 & 14.20 & 34.30 \\
Turner syndrome & F & 13.5 & 52.3 & 45.30 & 4.40 & 12.90 \\
Healthy & M & 13.5 & 3.38 & 4.74 & 0.04 & 0.01 \\
Healthy & $\mathrm{M}$ & 13.6 & 1.79 & 1.36 & 2.18 & 3.46 \\
\hline
\end{tabular}

${ }^{*} \mathrm{~F}$, female; M, male; U-FSH, urinary FSH; S-FSH, serum FSH; U-LH, urinary LH; S-LH, serum LH. 
a decrease in urinary gonadotropin concentrations during storage at -20 to $-25^{\circ} \mathrm{C}$ and suggested use of glycerol as a preservative. Repeated freezing and thawing of urine also decreased the FSH and LH levels. This is in contrast to a previous report by Landy et al. (36), who used RIA for measuring urinary gonadotropins, and reports of Kwekkeboom et al. (37), who used immunoradiometric assays.

Adding sodium azide or thymol to urine as a preservative did not affect FSH or LH levels. This makes it possible to measure urinary gonadotropins from samples collected for other purposes. Coating the tubes with BSA did not prove necessary in urinary gonadotropin measurements, whereas it is important in urinary GH assays (1). This may be because of the extremely low GH concentrations in urine. On the other hand, coating the tubes with BSA does not affect urinary $\mathrm{LH}$ and FSH measurements. Thus, the same urine samples can be used for assays of both $\mathrm{GH}$ and gonadotropins. All these facts contribute to the practicality of urine sampling. The absolute (uncorrected) values of urinary gonadotropins are very similar to the corresponding serum concentrations, which facilitates evaluation of the gonadotropin values without complex calculations. This is in contrast to urinary GH concentrations, which are only small fractions $(0.01 \%)$ of GH levels in plasma (38).

A potential drawback of urine is the dependence of urinary hormone levels on urinary flow; thus, very dilute urine may be expected to have reduced concentrations. We evaluated whether correction of urinary FSH and $\mathrm{LH}$ levels for density and creatinine concentration could improve the correlation with serum levels, but this was not the case. Overcorrection of results for urinary human chorionic gonadotropin with creatinine was also observed by Alfthan et al. (39). Interestingly, in a study on urinary $\mathrm{GH}$, values corrected for creatinine were not more accurate than uncorrected values (40). An ideal method for correction remains to be established. Overcorrection was especially a problem in young children, probably because the concentration capacity of the kidney in younger children is not yet fully developed. Therefore, urinary density or creatinine values are not reliable correction criteria. Regardless of variations in the density of urine samples or age of children, uncorrected urinary gonadotropin concentrations exhibit good correlation with corresponding serum levels. We observed few discrepancies in pairs of urinary and serum gonadotropin concentrations. The low serum and high morning urine LH values in some pairs may be due to the fact that morning urine reflects nighttime concentrations, which are relatively higher at the onset of puberty. High serum and low urine LH values might be caused by variations in the degradation of urinary $\mathrm{LH}$.

Measurement of gonadotropins in urine collected in the bladder over a period of time represents the integrated secreti 1 , which smooths the gonadotropin peaks in plasma. Thus, urine determinations have certain theoretical advantages, and our data demonstrate that the pre- sent highly sensitive urinary gonadotropin measurements can be used in children to estimate gonadotropin secretion.

Urinary gonadotropin measurements may have important clinical implications. As Morel et al. (41) also pointed out, urinary gonadotropin excretion may be a valuable parameter of the gonadotropic function, allowing one to separate delayed puberty from hypogonadotropic hypogonadism, to confirm a diagnosis of precocious puberty, and to control treatment with gonadotropin-releasing hormone analogs. Our data on Turner girls (Table 3 ) illustrate that urinary gonadotropin measurements are reliable also in hypergonadotropic states.

Acknowledgments. The authors thank Leo Dunkel, M.D., for valuable criticism of this manuscript. We are also indebted to Herman Williams, M.D., and Erika Hatva, M.D., for their assistance in language revision.

\section{REFERENCES}

1. Moreira-Andrés NM, Cañizo FJ. Hawkins F 1993 ls there a place for urinary growth hormone measurement? Acta Endocrinol 128:197-201

2. Baumann G, Abramson CE 1983 Urinary growth hormone in man: evidence for multiple molecular forms. J Clin Endocrinol Metab 56:305-311

3. Girard J, Erb T, Pampalone A. Eberle A, Baumann J 1987 Growth hormone in urine: development of an ultrasensitive assay applicable to plasma and urine. Horm Res $28: 71-80$

4. Tomita H, Ogawa M, Kamijo T, Mori O, Ishikawa E, Mohri Z., Murakami Y 1989 A highly sensitive sandwich enzyme immunoassay of urinary growth hormone in children with short stature, Turner's syndrome, and simple obesity. Acta Endocrinol 121:513-519

5. Pettersson KS, Söderholm JR 199) Ultrasensitive two-site immunometric assay of human lutropin by time-resolved fluorometry. Clin Chem 36:19281933

6. Apter D, Cacciatore B, Alfthan H, Stenman U-H 1989 Serum luteinizing hormone concentrations increase 10 )-fold in females from 7 years of age to adulthood, as measured by time-resolved immunofluorometric assay. J Clin Endocrinol Metab 68:53-57

7. Fitschen W, Clayton BE 1965 Urinary excretion of gonadotrophins with particular reference to children. Arch Dis Child 40:16-26

8. Kulin HE, Rifkind AB, Ross GT, Odell WO 1967 Total gonadotropin activity in the urine of prepubertal children. J Clin Endocrinol 27:1123-1128

9. Bagshawe KD, Wilde CE. Orr AH 1966 Radioimmunoassay for human chorionic gonadotrophin and luteinising hormone. Lancet 1:1118-1121

10. Rifkind A, Kulin HE, Cargille CM, Rayford PC, Ross GT 1970 24-hour urinary luteinizing hormone ( $\mathrm{LH})$ and follicle stimulating hormone (FSH) excretion in normal children. J Clin Endocrinol Metab 31:517-525

11. Kulin HE, Bell PM, Santen RJ, Ferher NJ 1975 Integration of pulsatile gonadotropin secretion by timed urinary measurements: an accurate and sensitive 3-hour test. J Clin Endocrinol Metab 40:783-789

12. Huhtaniemi 1, Ding Y-Q. Tähtelä R, Välimäki M 1992 The bio/immuno ratio of plasma luteinizing hormone does not change during the endogenous secretion pulse: reanalysis on the concept using improved immunoassay tech niques. J Clin Endocrinol Metab 75:1442-1445

13. Chappel $S 1990$ Biological to immunological ratios: reevaluation of a concept. $\mathrm{J}$ Clin Endocrinol Metab 70:1494-1495

14. Jaakkola T, Ding YQ, Kellokumpu LP, Valavaara R, Martikainen $H$, Tapanainen J, Ronnberg L, Huhtaniemi 1 199) The ratios of serum bioactive/ immunoreactive luteinizing hormone and follicle-stimulating hormone in various clinical conditions with increased and decreased gonadotropin secretion: reevaluation by a highly sensitive immunometric assay. J Clin Endocrinol Metab 70:1496-1505

15. Haavisto AM, Dunkel L, Pettersson K, Huhtaniemi I 1990 LH measurements by in vitro bioassay and a highly sensitive immunofluorometric assay improve the distinction between boys with constitutional delay of puberty and hypogonadotropic hypogonadism. Pediatr Res 27:211-214

16. Kulin H, Santner S 1977 Timed urinary gonadotropin measurements in normal infants, children and adults, and in patients with disorders of sexual maturation. J Pediatr 9():76(1)-765

17. Santen R, Kulin H 1986 Evaluation of Delayed Puberty and Hypogonadism. Marcel Dekker, New York, pp 145-189

18. Bourguignon J, Vanderschueren-Lodeweyckx M, Reuter M, Vrindts-Gevaer Y, Gerard A. Franchimont P 1980 Radioimmunoassays of unextracted gonadotrophins in timed fractions of 24-hour urine: morning increase of gonado- 
tropin excretion, a circadian pattern in relation to puberty. Hormone Res 13:367-384

19. Girard J, Baumann J, Ruch W 1980 Pathophysiology of Puberty. Academic Press, New York, pp 223-237

20. Girard J, Hadziselimovic F 1987 Relevance of urinary gonadotrophins. Eur J Pediatr 146:18-20

21. Maesaka H, Suwa S, Tachibana K, Kikuchi N 1990 Quantitation of urinary gonadotropins in normal children. Pediatr Res 28:401-404

22. Maesaka H, Suwa S, Tachibana K, Kikuchi N 1990 Monthly urinary LH and FSH secretory patterns in normal children and patients with sexual disorders. Pediatr Res 28:405-410

23. Lövgren T, Hemmilä I, Pettersson K, Eskola JU, Bertoft E 1984 Determination of hormones by time-resolved fluoroimmunoassay. Talanta 31:909-916

24. Stenman U-H, Alfthan H, Koskimies A, Seppälä M, Pettersson K, Lövgren T 1985 Monitoring the LH surge by ultrarapid and highly sensitive immunofluorometric assay. Ann NY Acad Sci 442:544-550

25. Dunkel L, Alfthan H, Stenman UH, Selstam G, Rosberg S, AlbertssonWikland K 1992 Developmental changes in 24-hour profiles of luteinizing hormone and follicle-stimulating hormone from prepuberty to midstages of puberty in boys. J Clin Endocrinol Metab 74:890-897

26. Wu FC, Butler GE, Kelnar CJ, Stirling HF, Huhtaniemi I 1991 Patterns of pulsatile luteinizing hormone and follicle-stimulating hormone secretion in prepubertal (midchildhood) boys and girls and patients with idiopathic hypogonadotropic hypogonadism (Kallmann's syndrome): a study using an ultrasensitive time-resolved immunofluorometric assay. J Clin Endocrinol Metab 72:1229-1237

27. Goji K, Tanikaze S 1992 Comparison between spontaneous gonadotropin concentration profiles and gonadotropin response to low-dose gonadotropinreleasing hormone in prepubertal and early pubertal boys and patients with hypogonadotropic hypogonadism: assessment by using ultrasensitive, timeresolved immunofluorometric assay. Pediatr Res 31:535-539

28. Dunkel L, Alfthan H, Stenman UH, Perheentupa J 1990 Gonadal control of pulsatile secretion of luteinizing hormone and follicle-stimulating hormone in prepubertal boys evaluated by ultrasensitive time-resolved immunofluorometric assays. J Clin Endocrinol Metab 70:107-114

29. Dunkel L, Alfthan H, Stenman UH, Tapanainen P. Perheentupa J 1990 Pulsatile secretion of LH and FSH in prepubertal and early pubertal boys revealed by ultrasensitive time-resolved immunofluorometric assays. Pediatr Res 27:215-219

30. Stenman U-H, Alfthan H, Turpeinen U 1991 Method dependence of interpretation of immunoassay results. Scand J Clin Lab Invest 51:86-94

31. Neven P, Iles RK, Howes I, Sharma K, Shepherd JH, Edwards R, Collins WP, Chard T 1993 Substantial urinary concentrations of material resembling $\beta$-core fragment of chorionic gonadotropin $\beta$-subunit in mid-menstrual cycle. Clin Chem 39:1857-1860

32. Franchimont P, Gaspard U, Reuter A, Heynen G 1972 Polymorphism of protein and polypeptide hormones. Clin Endocrinol 1:315-336

33. Young JL, Harsoulis P, Kuku SF, Fraser TR 1975 Gel filtration of human urinary immunoreactive luteinizing hormone. J Endocrinol 64:429-441

34. Beitins 1Z, Derfel L, O'Loughlin K, McArthur JW 1976 Immunoreactive luteinizing hormone, follicle stimulating hormone and their subunits in human urine following gel filtration. J Clin Endocrinol Metab 44:149-159

35. Livesey J, Roud H, Metcalf M, Donald R 1983 Glycerol prevents loss of immunoreactive follicle-stimulating hormone and luteinizing hormone from frozen urine. J Endocrinol 98:381-384

36. Landy H, Schneyer AL, Whitcomb RW, Crowley WJ 1990 Validation of highly specific and sensitive radioimmunoassays for lutropin, follitropin, and free alpha subunit in unextracted urine. Clin Chem 36:340-344

37. Kwekkeboom D, De Jong F, Lamberts S 1989 Confounding factors in the interpretation of gonadotropin and gonadotropin-subunit release from cultured human pituitary adenomas. J Steroid Biochem 33:777-782

38. Baumann G, Abramson G 1983 Urinary growth hormone in man: evidence for multiple molecular forms. J Clin Endocrinol Metab 56:301-311

39. Alfthan H, Haglund C, Dabek J, Stenman U-H 1992 Concentrations of human choriogonadotropin, its $\beta$-subunit, and the core fragment of the $\beta$-subunit in serum and urine of men and nonpregnant women. Clin Chem 38:1981-1987

40. Main K, Philips M, Jorgensen M, Skakkebk N 1991 Urinary growth hormone excretion in 657 healthy children and adults: normal values, inter- and intraindividual variations. Horm Res 36:174-182

41. Morel Y, La Selve H, Chatelain P, Perez J, Varenne J, De Peretti E, Forest M, David M, Bertrand J 1985 Intérêt du dosage des gonadotrophines urinaires en endocrinologie pédiatrique. Arch Fr Pediatr 42:579-585 